Article

\title{
Identification and Characterization of Nnematicidal Volatile Organic Compounds from Deep-Sea Virgibacillus dokdonensis MCCC $1 \mathrm{A00493}$
}

\author{
Dian Huang ${ }^{1}$, Chen $\mathrm{Yu}^{1}$, Zongze Shao ${ }^{2}$, Minmin Cai ${ }^{1}$, Guangyu Li ${ }^{2}{ }^{\mathbb{D}}$, Longyu Zheng ${ }^{1}$, \\ Ziniu Yu ${ }^{1}$ and Jibin Zhang ${ }^{1, *}$ \\ 1 State Key Laboratory of Agricultural Microbiology, National Engineering Research Center of Microbe \\ Pesticides, College of Life Science and Technology, Huazhong Agricultural University, Wuhan 430070, China; \\ hui8229hd@163.com (D.H.); yuchen921204@163.com (C.Y.); cmm114@mail.hzau.edu.cn (M.C.); \\ ly.zheng@mail.hzau.edu.cn (L.Z.); yz41@mail.hzau.edu.cn (Z.Y.) \\ 2 Key Laboratory of Marine Biogenetic Resources, Third Institute of Oceanography, Ministry of Natural \\ Resources, Xiamen 361005, China; shaozz@163.com (Z.S.); mccc_ligy@163.com (G.L.) \\ * Correspondence: zhangjb@mail.hzau.edu.cn; Tel.: +86-27-87287701; Fax: +86-27-87287254
}

Academic Editor: Derek J. McPhee

Received: 16 January 2020; Accepted: 6 February 2020; Published: 9 February 2020

\begin{abstract}
Root-knot nematode diseases cause severe yield and economic losses each year in global agricultural production. Virgibacillus dokdonensis MCCC 1A00493, a deep-sea bacterium, shows a significant nematicidal activity against Meloidogyne incognita in vitro. However, information about the active substances of $V$. dokdonensis MCCC $1 \mathrm{~A} 00493$ is limited. In this study, volatile organic compounds (VOCs) from $V$. dokdonensis MCCC 1A00493 were isolated and analyzed through solid-phase microextraction and gas chromatography-mass spectrometry. Four VOCs, namely, acetaldehyde, dimethyl disulfide, ethylbenzene, and 2-butanone, were identified, and their nematicidal activities were evaluated. The four VOCs had a variety of active modes on $M$. incognita juveniles. Acetaldehyde had direct contact killing, fumigation, and attraction activities; dimethyl disulfide had direct contact killing and attraction activities; ethylbenzene had an attraction activity; and 2-butanone had a repellent activity. Only acetaldehyde had a fumigant activity to inhibit egg hatching. Combining this fumigant activity against eggs and juveniles could be an effective strategy to control the different developmental stages of $M$. incognita. The combination of direct contact and attraction activities could also establish trapping and killing strategies against root-knot nematodes. Considering all nematicidal modes or strategies, we could use V. dokdonensis MCCC 1A00493 to set up an integrated strategy to control root-knot nematodes.
\end{abstract}

Keywords: virgibacillus dokdonensis; Meloidogyne incognita; volatile organic compound; fumigant; attraction; repellent; integrated strategy

\section{Introduction}

Plant-parasitic nematodes (PPNs) cause an annual loss of over $\$ 150$ billion in world crops [1]. Root-knot nematodes (RKNs) are obligate root parasites that infest more than 5000 plant species worldwide. Meloidogyne incognita is a RKN and one of the most severe PPNs worldwide [2,3], especially in tropical and subtropical agricultural areas [2,4-6]. This pathogen enters roots and establishes a feeding site, resulting in the formation of a large gall in a susceptible host [7]. These large galls impair the ability of plants to uptake water and nutrients, and they can lead to symptoms, such as wilting, stunting, chlorosis, and ultimately yield loss [8]. Infection by Meloidogyne spp. may predispose a plant to secondary pathogens $[7,9]$. Controlling Meloidogyne spp. is sometimes difficult because of their 
extensive host range, short life cycle, high reproductive rate, and endoparasitic nature [10]. Meloidogyne spp. are also difficult to control with a single control method [11]. Several management strategies, including crop rotations, developing and planting resistant varieties, use of chemical nematicides, and biological and physical control measures, can be applied to control RKNs [12-14]. Among them, chemical nematicides have been generally used because they are efficacious, can be easily applied, and have a rapid onset [15].

Although chemical nematicides are usually more effective than other strategies, they have caused significant environmental problems because of their toxic residues. For example, bromomethane, an effective soil fumigant, is no longer used because of its destructive potential to the stratospheric ozone [16]. Dibromochloropropane, known as an effective organochlorine nematicide, has been banned since 1979 because of its mutagenicity, carcinogenicity, and reproductive effects on humans [17]. Therefore, developing environment-friendly alternatives is urgently needed for PPN control.

PPNs usually exist in soil and are subjected to infection by indigenous bacteria and fungi in soil, thereby providing the possibility of using microorganisms to control PPNs [18]. Many microorganisms and their metabolites have been extensively studied, and they have shown great potential for the biological control of nematodes [19-21]. Volatile organic compounds (VOCs) obtained from terrestrial organisms have significant biological activities. Gu et al. evaluated the VOCs produced by 200 isolates of soil bacteria in in vitro experiments. Most soil bacteria show a nematicidal activity against PPNs. The detected VOCs include alcohols, aldehydes, ketones, alkenes, and ethers [22].

VOCs are small volatile compounds that can be fumigated at certain temperature and pressure to exert their insecticidal or bacteriostatic effects [23]. Microorganisms can release volatile substances in soil or other growth matrices, and the fumigation of these substances can be used to prevent and control plant diseases [24]. Cheng [25] et al. found that volatile substances produced by Paenibacillus polymyxa can control RKNs in many ways. Zhai [26] et al. detected seven volatile substances in the fermentation broth of Pseudomonas putida 1A00316; among them, 2-undecanone has shown a strong nematicidal activity. VOCs have a certain toxic effect on plant pathogens and can attract nematode natural enemies. As activation signal molecules of plant resistance-related genes, VOCs can enhance the resistance of plants to pathogens by activating the plant hormone-dependent signal pathway [27]. VOCs are generally less toxic to humans and livestock; hence, the development and application of online biological control agents have great potential.

Oceans cover more than $70 \%$ of the Earth's surface, and this proportion represents more than $95 \%$ of the biosphere by volume [28]. Deep-sea bacteria are abundant microbial resources found in these water bodies. Marine microorganisms have special living conditions, so they can often produce various active compounds with functions and structures that may be different from those found in terrestrial organisms. We previously reported the special antibacterial activity of Virgibacillus dokdonensis against Xanthomonas oryzae pv. oryzae [29]. The active compound 1-deoxy- $N$-acetylglucosamine was also extracted and identified. To our knowledge, few studies have described the nematicidal activity of volatiles from marine microorganisms and their potential use as substitutes for highly toxic chemical nematicides. Virgibacillus dokdonensis MCCC 1A00493 is originally isolated from deep-sea polymetallic nodules in the Eastern Pacific Ocean and exhibits a strong nematicidal activity against RKNs. In this study, the VOCs produced by MCCC 1A00493 and their multiple active mechanisms on Meloidogyne incognita were investigated.

\section{Results}

\subsection{Contact and Fumigant Nematicidal Activities of V. dokdonensis's Fermentation Supernatant against M. incognita J2s}

The fermentation supernatant of $V$. dokdonensis MCCC $1 \mathrm{~A} 00493\left(\mathrm{OD}_{600}=1.7\right)$ showed a high activity against $M$. incognita in vitro. The mortality rate was $100 \%(24 \mathrm{~h})$ when the nematode juveniles were exposed to the supernatant of MCCC 1A00493 at five times of dilution (Figure 1). The fumigant 
activity test also revealed that the6 MCCC 1A00493 culture could kill nematodes by producing volatiles. The nematicidal activity of this strain was $100 \%$ at $24 \mathrm{~h}$ (Figure 1).

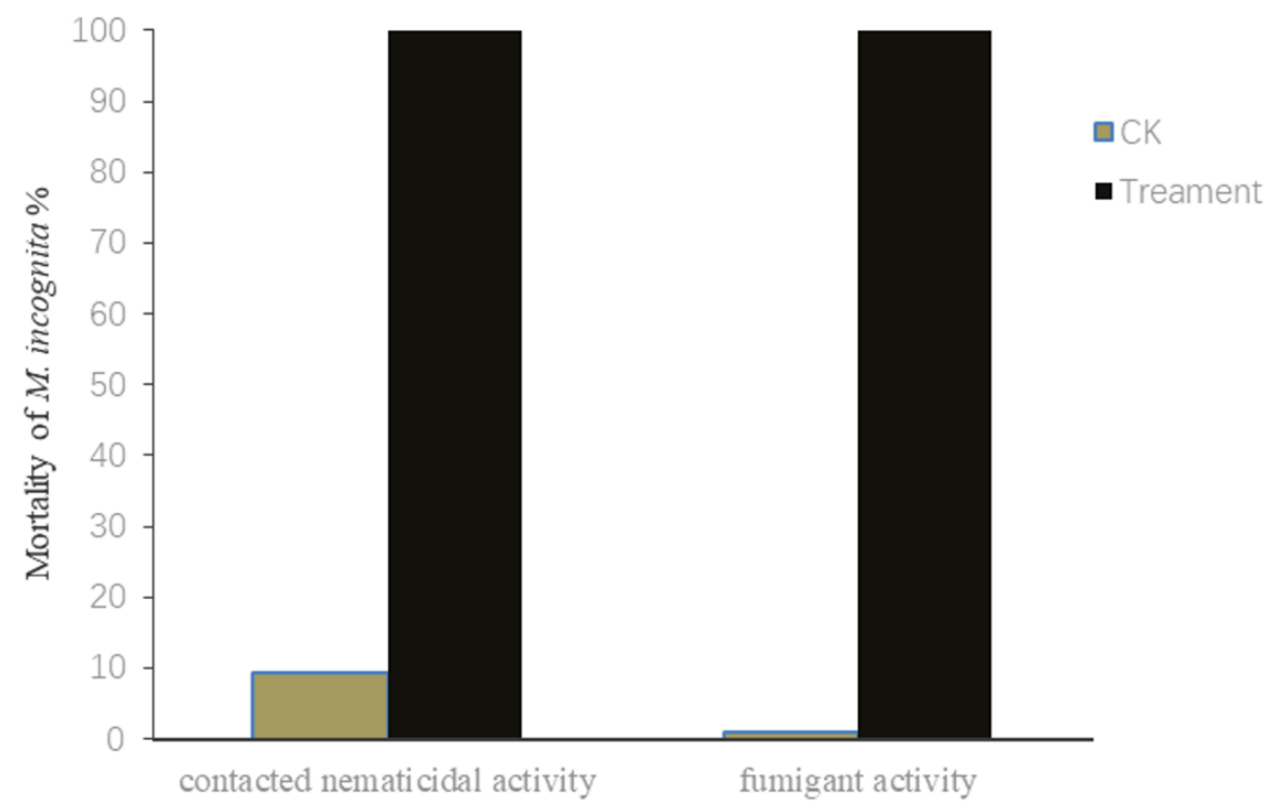

Figure 1. Nematicidal activity of $V$. dokdonensis (Treatment) and control group (CK) against M. incognita.

\subsection{Identification of the VOCs of $V$. dokdonensis}

Six peaks from the bacterial culture were observed in the total ion current chromatograms, and two peaks were detected in the 2216E medium through GC-MS analysis (Figure 2). After these peaks were compared with the mass spectrum of the substance from the GC-MS system data bank (NIST 08 library), four kinds of volatiles (acetaldehyde, 2-butanone, dimethyl disulfide, and ethylbenzene) produced by the bacterium and two kinds of volatiles (2,5-dimethyl pyrazine and benzaldehyde) in the 2216E medium were identified (Table 1). The MCCC 1 A00493 fermentation broth produced mixtures of VOCs and killed nematode juveniles. Four compounds, namely, acetaldehyde, 2-butanone, dimethyl disulfide, and ethylbenzene, were purchased for further experiments.

Table 1. Area percentage of the VOCs of the culture of $V$. dokdonensis MCCC 1A00493 through CAR/DVB extraction.

\begin{tabular}{ccccc}
\hline PK & RT & Area Pct & Library/ID & CAS \\
\hline 1 & 1.6566 & 17.7158 & Acetaldehyde & $000075-07-0$ \\
2 & 2.4153 & 3.1635 & 2-Butanone & $000078-93-3$ \\
3 & 4.4139 & 2.288 & Dimethyl disulfide & $000624-92-0$ \\
4 & 7.9255 & 0.977 & Ethylbenzene & $000100-41-4$ \\
5 & 9.7593 & 21.4172 & 2,5-Dimethyl pyrazine & $000123-32-0$ \\
6 & 11.5195 & 19.0497 & Benzaldehyde & $000100-52-7$ \\
\hline
\end{tabular}

\subsection{Nematicidal Activity of VOCs against M. incognita J2s}

The four VOCs produced by the bacterium were taken as the nematicidal candidates, and their nematicidal efficacy was measured in vitro by using commercial compounds as described before (Table 1). Two VOCs (acetaldehyde and dimethyl disulfide) from the four tested candidates exhibited strong nematicidal activities against juveniles at a concentration of $1 \mathrm{mg} / \mathrm{mL}$. After being exposed to acetaldehyde and dimethyl disulfide for $24 \mathrm{~h}$, the nematodes died, their body shape straightened, and the inner tissues were destroyed entirely (Figure 3). After acetaldehyde and dimethyl disulfide treatments were administered, the RKNs presented a stiff and dead state, and the intestinal tissue in the 
body cavity was not clear and was suspected to be damaged. The nematicidal activity of acetaldehyde had $\mathrm{EC}_{50}$ of $141.4 \mu \mathrm{g} / \mathrm{mL}$ at $6 \mathrm{~h}$ and below $10 \mu \mathrm{g} / \mathrm{mL}$ at $24 \mathrm{~h}$. The nematicidal activity of dimethyl disulfide had $\mathrm{EC}_{50}$ of $139.1 \mu \mathrm{g} / \mathrm{mL}$ at $24 \mathrm{~h}$. The $\mathrm{EC}_{50}$ values of 2-butanone and ethylbenzene were not evaluated because of their low nematicidal activity at $1 \mathrm{mg} / \mathrm{mL}$ (Table 2).
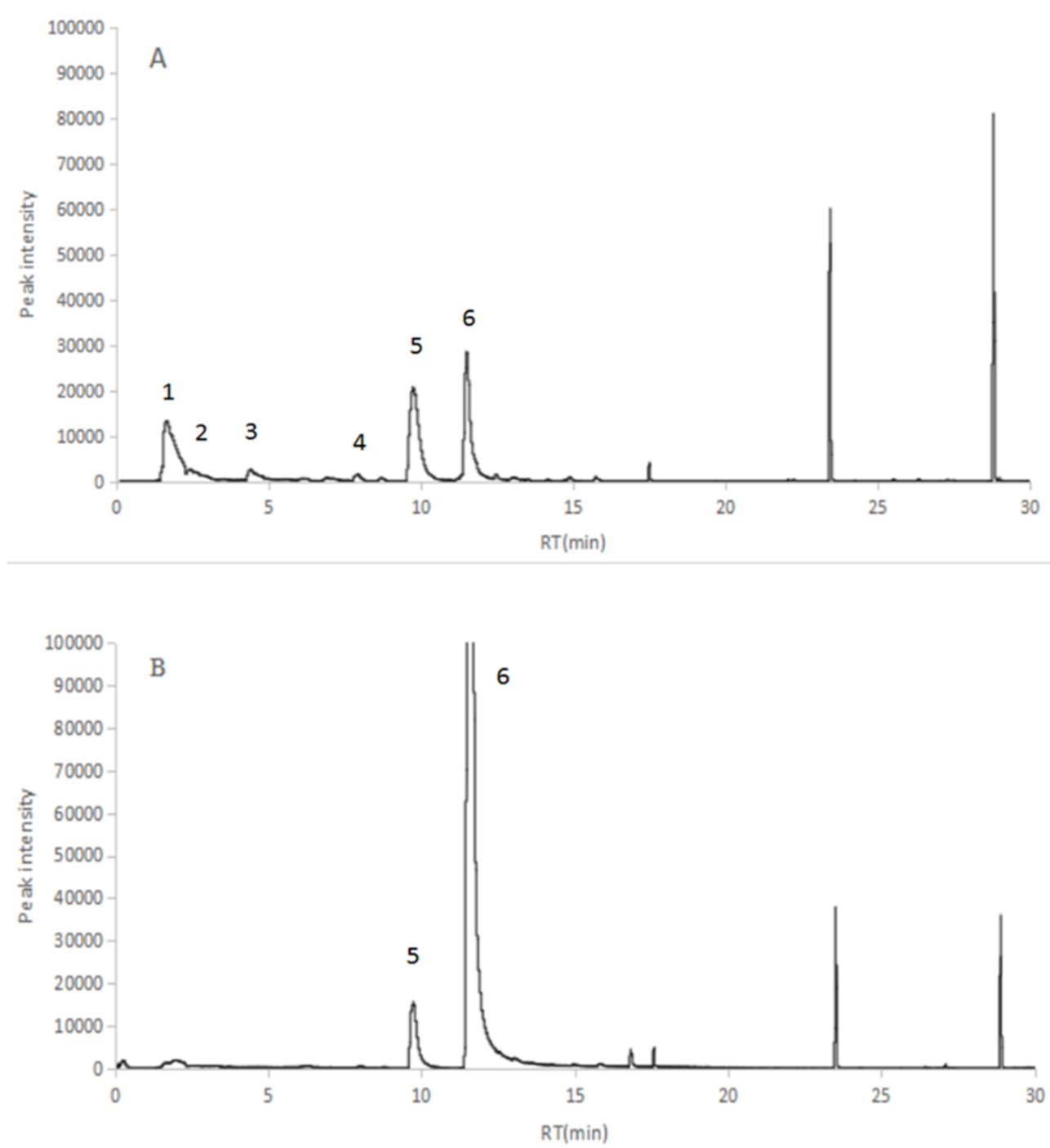

Figure 2. Chromatograms of VOCs in the TIC mode via CAR/DVB extraction. (A) Culture of $V$. dokdonensis 1A00493; (B) 2216E medium.

Table 2. Contact nematicidal activity of the VOCs against $M$. incognita.

\begin{tabular}{cc}
\hline & $\mathrm{EC}_{\mathbf{5 0}}(\mathbf{m g} / \mathrm{L})$ \\
\cline { 2 - 2 } Compound & $\mathbf{2 4} \mathbf{~ h}$ \\
\hline Acetaldehyde & $<3$ \\
Dimethyl disulfide & 139.1 \\
2-Butanone & $>1000$ \\
Ethylbenzene & $>1000$ \\
\hline
\end{tabular}

\subsection{Fumigant Activity of VOCs against Juveniles and Eggs}

The fumigant activity of volatiles against juveniles was tested in 96-well plates. At $10 \mathrm{mg} / \mathrm{mL}$, only acetaldehyde had a fumigant activity against J2 (Figure 3), whereas the mortality of the three other volatiles was less than $10 \%$. Even when the concentration of acetaldehyde was reduced to 1 
$\mathrm{mg} / \mathrm{mL}$, its fumigation effect was still obvious, and the mortalities of the nematodes were $70.1 \%$ at $6 \mathrm{~h}$ and $98.0 \%$ at $24 \mathrm{~h}$ (Table 3).
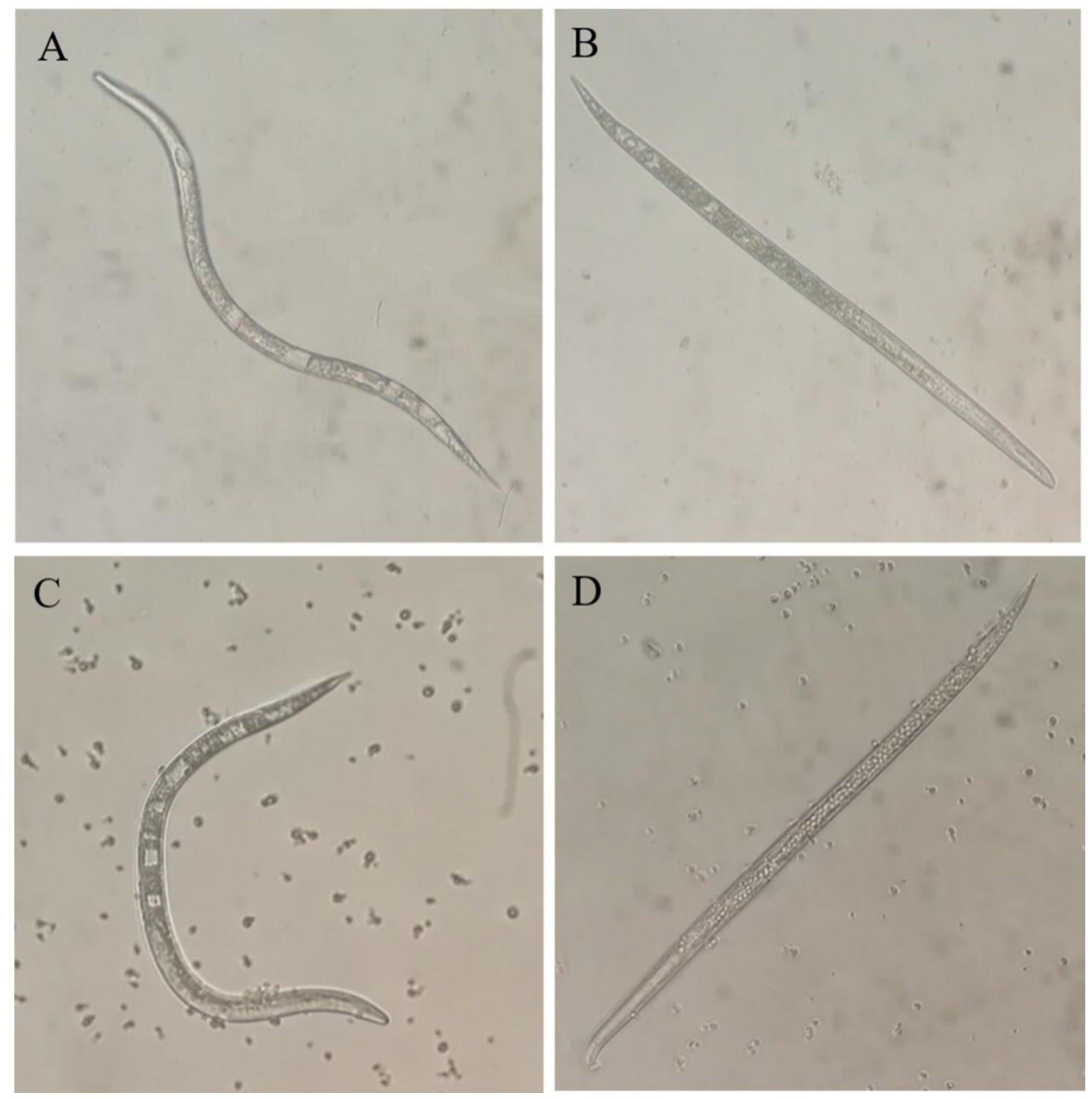

Figure 3. Morphological variations in $M$. incognita J2s after acetaldehyde and dimethyl disulfide treatments. (A) Treated with $\mathrm{H}_{2} \mathrm{O}$ for $24 \mathrm{~h}$; (B) treated with $10 \mathrm{mg} / \mathrm{mL}$ acetaldehyde for $24 \mathrm{~h}$; (C) treated with $0.3 \%$ Tween 20 for $24 \mathrm{~h}$; (D) treated with $10 \mathrm{mg} / \mathrm{mL}$ dimethyl disulfide for $24 \mathrm{~h}$.

Table 3. Fumigant activity of VOCs against M. incognita.

\begin{tabular}{ccc}
\hline & \multicolumn{2}{c}{ Mortality (\%) $\pm \mathbf{S D}$} \\
\hline & $\mathbf{6} \mathbf{h}$ & $\mathbf{2 4} \mathbf{~ h}$ \\
\hline $10 \mathrm{mg} / \mathrm{mL}$ acetaldehyde & 100 & 100 \\
$1 \mathrm{mg} / \mathrm{mL}$ acetaldehyde & $70.0 \pm 12.0$ & $97.9 \pm 2.4$ \\
$10 \mathrm{mg} / \mathrm{mL}$ 2-butanone & 0 & $1.4 \pm 1.9$ \\
$10 \mathrm{mg} / \mathrm{mL}$ dimethyl disulfide & 0 & $7.9 \pm 1.6$ \\
$10 \mathrm{mg} / \mathrm{mL}$ ethylbenzene & 0 & $1.3 \pm 1.6$ \\
\hline
\end{tabular}

We also tested acetaldehyde's fumigant activity to inhibit egg hatching. The three other compounds were not further tested because only acetaldehyde showed a fumigant activity against J2s and had the highest nematicidal activity among the VOCs. Egg hatching was remarkably inhibited at $10 \mathrm{mg} / \mathrm{mL}$. 
The average number of the hatched juveniles per egg mass after three days of acetaldehyde treatment was 3.8, whereas the average number of the hatched juveniles per egg mass of the control treatment was 77.6 (Table 4). However, $1 \mathrm{mg} / \mathrm{mL}$ acetaldehyde temporarily inhibited egg hatching. Acetaldehyde was more efficacious in lessening the number of the hatched juveniles than MCCC 1A00493 culture treatment. We also observed 100\% mortality of the hatched juveniles in MCCC 1A00493 culture treatment and $10 \mathrm{mg} / \mathrm{mL}$ acetaldehyde treatment. Therefore, fumigating juveniles and eggs was an effective method to control M. incognita.

Table 4. Effect of acetaldehyde and bacterial culture to M. incognita's egg hatching.

\begin{tabular}{cccc}
\hline & \multicolumn{3}{c}{ Hatched Worms Per Egg Mass \pm SD } \\
\hline & $\mathbf{1}$ day & $\mathbf{2}$ days & $\mathbf{3}$ days \\
\hline $1 \mathrm{mg} / \mathrm{mL}$ acetaldehyde & $17.3 \pm 7.0 \mathrm{~b}$ & $37.4 \pm 13.3 \mathrm{ab}$ & $77.1 \pm 6.0 \mathrm{a}$ \\
$10 \mathrm{mg} / \mathrm{mL}$ acetaldehyde & $3.7 \pm 2.3 \mathrm{~b}$ & $3.8 \pm 2.3 \mathrm{c}$ & $3.8 \pm 2.3 \mathrm{~b}$ \\
$1 \mathrm{~A} 00493$ culture & $18.7 \pm 8.8 \mathrm{~b}$ & $18.9 \pm 8.7 \mathrm{bc}$ & $19.6 \pm 8.4 \mathrm{~b}$ \\
control & $43.9 \pm 21.0 \mathrm{a}$ & $62.4 \pm 23.7 \mathrm{a}$ & $77.6 \pm 25.7 \mathrm{a}$ \\
\hline
\end{tabular}

The number represents the means of the replicates \pm SD. Experimental data were analyzed using SPSS 17.0. Comparison between groups was analyzed through single-factor ANOVA. Different lowercase letters indicate significant difference between treatments $(p<0.05)$.

\subsection{Chemotaxis of M. incognita toward Ethylbenzene, Dimethyl disulfide, Acetaldehyde, and 2-Butanone}

Three volatiles (acetaldehyde, dimethyl disulfide, and ethylbenzene) could attract nematodes moving toward the test solution site. Acetaldehyde treatment had a C.I. of 0.1610, 0.3494, and 0.2065 from high concentration to low concentration; therefore, acetaldehyde showed an attracting activity. Dimethyl disulfide could attract nematodes at 3 and $1 \mathrm{mg} / \mathrm{mL}$ with a C.I. of 0.4280 and 0.3651 , respectively. Ethylbenzene showed an attracting activity at concentrations of 10 and $3 \mathrm{mg} / \mathrm{mL}$ with a C.I. of 0.2137 and 0.5540 , respectively. The chemotaxis of 2-butanone was unstable because it had a C.I. fluctuating at 0 and at different concentrations; hence, 2-butanone had a repellent activity (Figure 4 ).

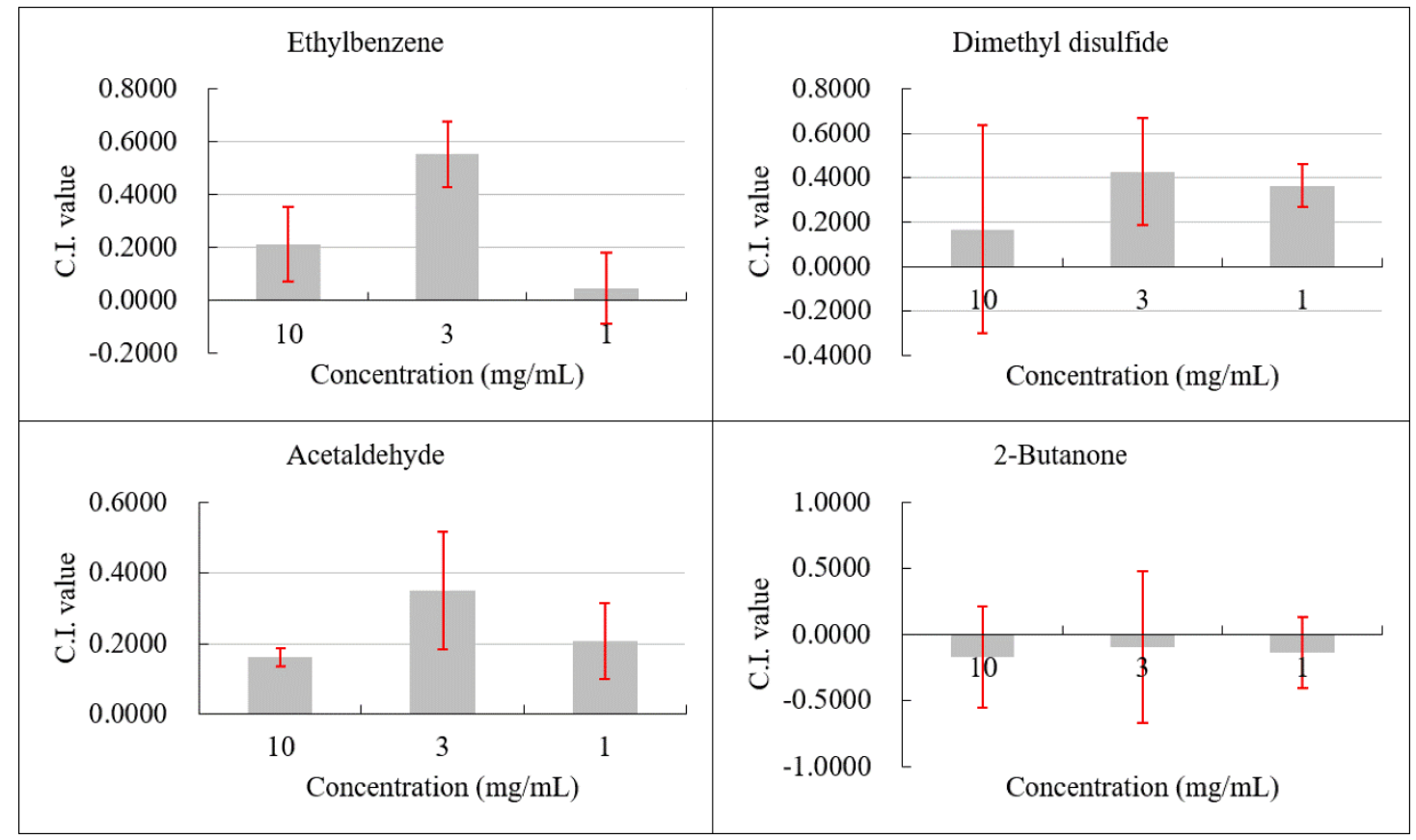

Figure 4. Attracting effect of VOCs on M. incognita. 


\section{Discussion}

Many VOCs that inhibit RKNs are extracted from plant tissues, such as leaves and seeds. Barros et al. [30] studied the nematicidal activity of VOCs emitted by Brassica juncea, Azadirachta indica, Canavalia ensiformis, Mucunapruriens, and Cajanus cajan against M. incognita. Plant VOCs contain diverse molecules that affect the mobility, pathogenicity, and reproduction of $M$. incognita. The nematicidal activity of fresh rucola used for soil amendment in a containerized culture of tomato alleviates nematode infection in a dose-response manner $\left(\mathrm{EC}_{50}=20.03 \mathrm{mg} / \mathrm{g}\right)$ and improves plant growth. The VOCs identified via GC-MS have a strong nematicidal activity against RKNs with low $\mathrm{EC}_{50}$ [31]. Studies about nematicidal VOCs from bacteria have been published. VOCs emitted by various bacteria into the chemosphere play a substantial role in antagonistic interactions between microorganisms occupying the same ecological niche and between bacteria and target eukaryotes [32]. Xu et al. identified bacterial VOCs produced by five bacterial strains (Pseudochrobactrum saccharolyticum, Wautersiella falsenii, Proteus hauseri, Arthrobacter nicotianae, and Achromobacter xylosoxidans). VOCs cover a wide range of aldehydes, ketones, alkyls, alcohols, alkenes, esters, alkynes, acids, ethers, and heterocyclic, and phenolic compounds [33].

MCCC 1A00493 produced four kinds of VOCs as identified via GC-MS. In most studies on VOCs of bacteria or fungi, the species of VOCs are generally more than 10 or even over 30 . However, only few VOCs were identified in this study. On the one hand, the changes in marine strains under land experimental conditions might not be conducive to the production of their metabolites. On the other hand, some VOCs might not have separated during extraction because of their low content or other factors, such as limitations of technical methods. Consistently, only few VOCs have been identified in marine strains in another study [34]. In the present study, volatiles from the deep-sea bacterial strain $V$. dokdonensis MCCC 1A00493 displayed a strong nematicidal activity against $M$. incognita and had different gas chromatographic profiles. Four main components of the volatiles were identified via GC-MS and their nematicidal activities were confirmed using commercial compounds, thereby making them easily available for the management of RKN disease in the future.

We demonstrated that $V$. dokdonensis MCCC 1A00493 showed strong nematicidal activities against RKN through the production of nematicidal volatiles. This study was the first to report the nematicidal volatiles of deep-sea bacteria. Among these VOCs, acetaldehyde and dimethyl disulfide had a contact nematicidal activity. Only acetaldehyde had a fumigation activity against $M$. incognita J2s and could inhibit egg hatching. Acetaldehyde, dimethyl disulfide, and ethylbenzene showed attraction activities, whereas 2-butanone had a weak repellent activity. The C.I. value at $10 \mathrm{mg} / \mathrm{mL}$ was lower than that at 3 $\mathrm{mg} / \mathrm{mL}$ because volatile solutions (acetaldehyde, dimethyl disulfide, and ethylbenzene) with a high concentration of $10 \mathrm{mg} / \mathrm{mL}$ might paralyze nematode juveniles and make them move slowly. At $8 \mathrm{~h}$ of chemotaxis assay, some of the juveniles moved out from the center of the plate, and some juveniles stayed in the central spot. Another reason was that a high concentration of volatile compounds has a repellent effect on nematode. Few studies on ethylbenzene and 2-butanone have been conducted. Acetaldehyde is widely reported as an insect attractant and insecticide [35] and can be used for the antiseptic and sterilizing effects of fruit and vegetable fumigants [36,37]. Acetaldehyde is a product of ethanol metabolism in vivo and has a certain toxic effect. However, acetaldehyde's nematicidal activity has yet to be reported. Similar to acetaldehyde, dimethyl disulfide can be used as an insect attractant and insecticide; it is also an effective component in many insecticides and attractants [38,39]. Dimethyl disulfide is a potential biological insecticide for the control of tomato RKN [40]. Dimethyl disulfide had also been reported to have the strongest nematicidal activity (LC90 $=0.162 \mathrm{mmol} / \mathrm{L}$ ) against Bursaphelenchus xylophilus in direct contact for $24 \mathrm{~h}$ [34]. Huang et al. [41] found that dimethyl disulfide is active against $M$. incognita juveniles and eggs. Therefore, dimethyl disulfide has been widely studied as a fumigant, which has a good field application effect on RKNs and some fungal diseases. Dimethyl disulfide slightly affects the soil microbial community in the environment. Therefore, this VOC can be used as a soil fumigant instead of bromomethane [42], which has been forbidden for soil fumigation in China since December 30, 2018. 
The toxicity of acetaldehyde and dimethyl disulfide to RKN is unclear. Obvious differences were observed in the morphological characteristics and internal tissues between the untreated RKNs and RKNs treated with acetaldehyde and dimethyl disulfide. The tissues, including the intestine and pharynx, in the cavity of untreated RKNs (Figure 4) are relatively complete. However, in the treated RKNs (Figure 4), only the esophagus and pharynx are complete, and the intestinal tissue in the cavity of the lower part of the worm body is damaged. Further research is needed to understand the molecular mechanisms responsible for contact nematicidal activities.

Each VOC produced by MCCC 1A00493 has different effects on RKNs. Multiple VOCs can be used to simultaneously control RKNs $[43,44]$. The mixture of VOCs produced by bacteria may be more effective to control nematodes than treatment with synthetic nematicides composed of a single compound [44]. The VOCs produced by MCCC 1A00493 have the following control modes: direct contact, fumigation, attraction, and repellent activities. Volatile substances are more effective than nonvolatile nematicides in the control of RKNs. RKNs could not be acted upon by nematicides, but VOCs could inhibit or kill RKNs through fumigation or could control RKNs by trapping and repelling, that is, to attract nematodes to move to the application area and kill them. The VOCs of MCCC 1A00493 could kill M. incognita J2s through fumigation and inhibit the hatching of its eggs through fumigation. Nematicidal agents could not directly come in contact with eggs on plant roots and juveniles in soils, but these VOCs could effectively inhibit the hatching of nematode eggs. Even few juveniles were inhibited and killed through fumigation. This result showed that VOCs could simultaneously inhibit egg hatching and juvenile development, reduce the population number of RKNs, and control the different development stages of RKNs. Overall, we could establish an integrated strategy or system combining the different functions of nematicidal volatiles on RKNs. The specific mode of action should be further tested in the field.

\section{Materials and Methods}

\subsection{Bacterial Material}

$V$. dokdonensis MCCC 1A00493, which has a strong nematicidal activity, was isolated from polymetallic nodules in the East Pacific Ocean (depth: $4754 \mathrm{~m}$ ). The bacterium was stored at $4{ }^{\circ} \mathrm{C}$ on $2216 \mathrm{E}$ medium for a short time. A loop of the fresh culture was transferred into a polyamide bottle containing $10 \mathrm{~mL}$ of $2216 \mathrm{E}$ medium to produce liquid cultures for the experiments. The liquid cultures were incubated in a rotary shaker $(180 \mathrm{r} / \mathrm{min})$ at $28^{\circ} \mathrm{C}$ for $20 \mathrm{~h}$ as seed liquid. Then, $1 \mathrm{~mL}$ of seed fluid was added to a $250 \mathrm{~mL}$ conical flask containing $100 \mathrm{~mL}$ of $2216 \mathrm{E}$ medium and incubated in a rotary shaker $(180 \mathrm{r} / \mathrm{min})$ at $28^{\circ} \mathrm{C}$ for $48 \mathrm{~h}$. Bacterial culture was used in subsequent experiments.

\subsection{Chemicals}

The following chemicals were used: acetaldehyde (99.5\%; Aladdin, shanghai, China); dimethyl disulfide (>98\%; TIC Corporation Limited, shanghai, Japan); ethylbenzene (99.5\%; Macklin, shanghai, China); 2-butanone (99.0\%; Sinopharm Chemical Reagent Company, shanghai, China); and Tween 20 (Biosharp, shanghai, China).

\subsection{Nematode Population}

A population of M. incognita was reared on susceptible tomato plants in a greenhouse in State Key Laboratory of Agricultural Microbiology, Wuhan, China, for two months at $25 \pm 2{ }^{\circ} \mathrm{C}$. Infested plants were uprooted, and roots with numerous large galls and egg masses were gently washed to remove soil. Egg masses were picked and transferred to 96-well plates, and distilled water was used as a natural hatching agent. The egg masses were incubated at room temperature to obtain juveniles. After hatching, the juveniles were collected, and a suspension of second-stage juveniles (J2s) was prepared in distilled water. 


\subsection{GC-MS Analysis}

Solid-phase microextraction (SPME) and gas chromatography-mass spectrometry (GC-MS) were conducted for VOC extraction and analysis [45]. The MCCC 1A00493 was cultured, and its volatiles were collected in accordance with the methods described by Di'az et al. [46]. A new $75 \mu \mathrm{m}$ carboxen/polydimethylsiloxane fiber (Supelco, Bellefonte, PA, USA) used for SPME was equilibrated with helium at $270{ }^{\circ} \mathrm{C}$ for $15 \mathrm{~min}$. Extractions were then performed inside $15 \mathrm{~mL}$ Supelco SPME vials filled with $9 \mathrm{~mL}$ of bacterial culture or 2216E liquid medium containing a stir bar [34]. An SPME needle was used to pierce the septum, and the fiber was exposed to the headspace of the vial. Extraction was performed at $60^{\circ} \mathrm{C}$ for $1 \mathrm{~h}$ with constant magnetic stirring. The volatiles from the 2216E liquid medium were used as control. Each sample was tested three times.

After extraction, the fiber was directly inserted into the injection port of the GC-MS instrument (Hewlett-Packard (HP) 7890A-5975C, Agilent Technologies, USA) and desorbed at $270{ }^{\circ} \mathrm{C}$ for $2 \mathrm{~min}$. The GC/MS instrument was equipped with a DB-5MS capillary column $(30 \mathrm{~m} \times 0.25 \mathrm{~mm} \times 0.25 \mu \mathrm{m})$. The carrier gas was helium with a flow rate of $1 \mathrm{~mL} / \mathrm{min}$. The program used to control the temperature of the oven was $40{ }^{\circ} \mathrm{C}$ for $2 \mathrm{~min}, 40^{\circ} \mathrm{C}-180{ }^{\circ} \mathrm{C}$ at a rate of $4{ }^{\circ} \mathrm{C} / \mathrm{min}, 180^{\circ} \mathrm{C}-240{ }^{\circ} \mathrm{C}$ at $5^{\circ} \mathrm{C} / \mathrm{min}$, and held at $240{ }^{\circ} \mathrm{C}$ for $6 \mathrm{~min}$. The temperatures of the transfer line and ion trap were $150{ }^{\circ} \mathrm{C}$ and $250{ }^{\circ} \mathrm{C}$, respectively. The volatile compounds were identified from the database search through the comparison of their mass spectrum with the GC/MS system data bank of the National Institute of Standards and Technology (NIST 08).

\subsection{Nematicidal Activity Bioassays of the Fermentation Supernatant and VOCs of MCCC 1A00493}

The fermentation supernatant of MCCC 1A00493 was prepared. VOCs were also prepared in distilled water containing Tween 20, and the final concentration of Tween 20 in the treatment was $0.3 \%$.

The contact nematicidal activity of the fermentation supernatant or VOCs of MCCC 1A00493 was tested. The sample $(100 \mu \mathrm{L})$ was added to one well in a 96-well plate with a nematode suspension containing about 60 worms. The plates were immediately wrapped with Parafilm. After incubation at room temperature $\left(20-25{ }^{\circ} \mathrm{C}\right)$, the mobile (live) and immobile juveniles were observed under an inverted microscope (Olympus, IX73). M. incognita was considered dead when no movement was observed for $2 \mathrm{~s}$ after it was touched with a needle. Mortality values were corrected by eliminating natural death in a negative control in accordance with Schneider-Orelli's formula [47], which is expressed as follows:

$$
\begin{gathered}
\text { Mortality }=[(\text { mortality percentage in treatment }- \text { mortality percentage in control }) \\
/(1-\text { mortality percentage in control })] \times 100 \% .
\end{gathered}
$$

\subsection{Fumigant Activity of the Fermentation Supernatant and VOCs of MCCC 1 A00493 against M. incognita Juveniles}

The fumigant activity of the fermentation supernatant and VOCs of MCCC 1A00493 was tested [48] by adding $200 \mu \mathrm{L}$ of the fermentation supernatant or VOC solution to one well in the center of a 96-well plate. The concentration of VOCs was set as $10 \mathrm{mg} / \mathrm{mL}$, and nematode juveniles with $100 \mu \mathrm{L}$ of $\mathrm{ddH}_{2} \mathrm{O}$ were added to the four wells adjacent to the test sample. The nematodes were prepared as above. The plates were immediately wrapped with Parafilm to prevent the escape of the volatiles. After incubation at room temperature $\left(20-25^{\circ} \mathrm{C}\right)$ for $24 \mathrm{~h}$, the mobile (live) and immobile juveniles were observed under an inverted microscope (Olympus, IX73).

\subsection{Fumigant Activity of VOCs to Inhibit Egg Hatching}

The method used in this experiment was similar to the test of fumigant activity to juveniles. Egg masses were collected from the infested roots and washed with $\mathrm{ddH}_{2} \mathrm{O}$ to remove soil. The nematodes in each well were replaced with a single egg mass, which was hatched in distilled water and used as 
control. The number of hatched worms was counted under the microscope after 1, 2, and 3 days. Each treatment was repeated three times.

\subsection{Chemotaxis Test}

A chemotaxis mode (Figure. 5) was designed in accordance with previously described methods with some modifications $[49,50]$. About 100 juveniles were placed in the center of $2 \%$ water agar plate. A volatile compound solution ( $30 \mu \mathrm{L}$ of 10,3 , and $1 \mathrm{mg} / \mathrm{mL}$ ) was added to a round paper $\left(1 \mathrm{~cm}^{2}\right) 4 \mathrm{~cm}$ away from the center of the assay plate. Tween-20 $(30 \mu \mathrm{L})$ was added to the paper on the opposite side of the VOC solution as control.

The number of worms at the test location or the control location was counted under an inverted microscope after incubation in the assay plate at $20^{\circ} \mathrm{C}$ for $8 \mathrm{~h}$. The juveniles that remained within 0.4 $\mathrm{cm}$ of the midline were not counted for chemotaxis assays. The chemotaxis index (C.I.) was finally calculated with the following formula [51]:

C.I. $=$ (the number of worms at the test location - the number of worms at the control location)/total number of worms on the plate.

A C.I. between 0 and 1 means an attracting activity, whereas a C.I. between -1 and 0 means a repellent activity.

The experiment was repeated twice and carried out in triplicate (Figure 5).

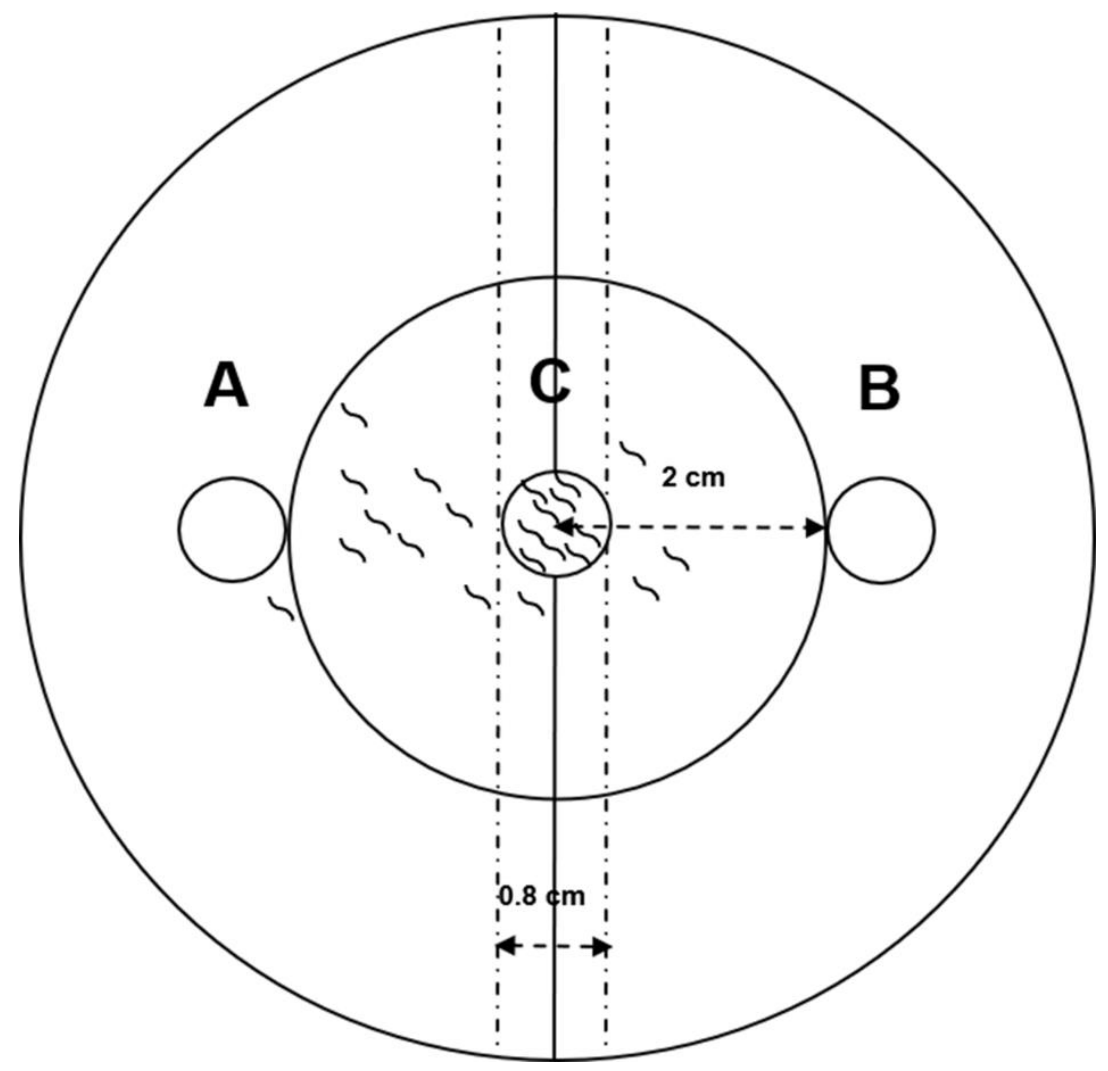

Figure 5. Chemotaxis mode. (A) Test location, (B) control location, and (C) center of the plate.

\subsection{Data Analysis and Atatistics}

Data were analyzed by using ANOVA, and means were compared through least significant differences (Duncan) at $p=0.05$ by using SPSS 17.0 for Windows. 


\section{Conclusions}

In summary, we isolated four kinds of volatiles (acetaldehyde, 2-butanone, dimethyl disulfide, and ethylbenzene) produced from $V$. dokdonensis MCCC 1A00493. The four VOCs had a variety of active modes on $M$. incognita juveniles. Acetaldehyde had direct contact killing, fumigation, and attraction activities; dimethyl disulfide had direct contact killing and attraction activities, ethylbenzene had an attraction activity; and 2-butanone had a repellent activity. Only acetaldehyde had a fumigant activity to inhibit egg hatching. Combination of direct contacted killing and attraction make nematicidal agents can trap and kill nematodes. Nematicidal volatiles also could kill nematode and inhibit egg hacthing by fumigation. V. dokdonensis MCCC 1 A00493 control nematodes through multi-mode, multi-function integrated strategy. This suggests that bacterial volatiles represent an important source for new natural nematicidal compounds that may be developed as novel nematicidal agents. And an integrated strategy which was more effective than current method could be established to control RKNs.

Author Contributions: Conceptualization: D.H. and J.Z.; formal analysis: M.C. and L.Z.; methodology: D.H. and C.Y.; resources: Z.S. and G.L.; validation: D.H. and C.Y.; writing-original draft: D.H. and C.Y.; writing-review and editing: Z.Y. and J.Z. All authors have read and agreed to the published version of the manuscript.

Funding: This work was supported by the project from China Ocean Mineral Resources Research and Development Association (DY135-B2-17) and the Major Projects of Technological Innovation in Hubei Province, China (2017ABA072).

Conflicts of Interest: The authors declare no competing financial interest.

\section{References}

1. Li, J.; Zou, C.; Xu, J.; Ji, X.; Niu, X.; Yang, J.; Huang, X.; Zhang, K.Q. Molecular mechanisms of nematode-nematophagous microbe interactions: Basis for biological control of plant-parasitic nematodes. Annu. Rev. Phytopathol. 2015, 53, 67-95. [CrossRef]

2. Jones, J.T.; Aegeman, A.; Danchin, E.G.; Gaur, H.S.; Helder, J.; Jones, M.G.; Kikuchi, T.; Manzanilla-López, R.; Palomares-Rius, J.E.; Wesemael, W.M.; et al. Top 10 plant-parasitic nematodes in molecular plant pathology. Mol. Plant Pathol. 2013, 14, 946-961. [CrossRef] [PubMed]

3. Liu, T.; Meyer, S.L.F.; Chitwood, D.J.; Chauhan, K.R.; Dong, D.; Zhang, T.T.; Li, J.; Liu, W.C. New nematotoxic indoloditerpenoid produced by Gymnoascus reessii za-130. J. Agric. Food Chem. 2017, 65, 3127-3132. [CrossRef] [PubMed]

4. Perry, R.N. Plant Parasitic Nematodes in Subtropical and Tropical Agriculture, 2nd ed.; Luc, M., Sikora, R.A., Bridge, J., Eds.; CABI Publishing: Wallingford, UK, 2005; p. 896.

5. Janssen, T.; Karssen, G.; Verhaeven, M.; Coyne, D.; Bert, W. Mitochondrial coding genome analysis of tropical root-knot nematodes (Meloidogyne) supports haplotype based diagnostics and reveals evidence of recent reticulate evolution. Sci. Rep. 2016, 6, 22591. [CrossRef] [PubMed]

6. Hajihassani, A.; Rutter, W.; Schwarz, T.; Woldemeskel, M.; Ali, M.E.; Hamidi, N. Characterization of resistance to major tropical root-knot nematodes (Meloidogyne spp.) in Solanum sisymbriifolium. Phytopathology 2019. [CrossRef] [PubMed]

7. Karssen, G.; Wesemael, M.; Moens, M. Root-knot nematodes. In Plant Nematology, 2nd ed.; Perry, R.N., Moens, M., Starr, J.L., Eds.; CABI Publishing: Wallingford, UK, 2013; pp. 74-108.

8. Duncan, L.W.; Moens, M. Migratory endoparasitic nematodes. In Plant Nematology, 2nd ed.; Perry, R.N., Moens, M., Eds.; CABI Publishing: Wallingford, UK, 2006; pp. 123-152.

9. Shahbaz, M.U.; Mukhtar, T.; Irfanulhaque, M.; Begum, N. Biochemical and serological characterization of ralstonia solanacearum associated with chilli seeds from pakistan. Int. J. Agric. Biol. 2015, 17, 31-40.

10. Verdejo-Lucas, S.; Talavera, M. Root-knot nematodes on zucchini (Cucurbita pepo subsp. pepo): Pathogenicity and management. Crop Prot. 2019, 126, 104943.

11. Al-Hazmi, A.S.; Dawabah, A.A.; Al-Nadhari, S.N.; Al-Yahya, F.A. Comparative efficacy of different approaches to managing Meloidogyne incognita on green bean. Saudi J. Bio. Sci. 2017, 24, 149-154. [CrossRef] 
12. Collange, B.; Navarrete, M.; Peyre, G.; Mateille, T.; Tchamitchian, M. Root-knot nematode (Meloidogyne) management in vegetable crop production: The challenge of an agronomic system analysis. Crop Prot. 2011, 30, 1251-1262. [CrossRef]

13. Ntalli, N.G.; Caboni, P. Botanical nematicides in the mediterranean basin. Phytochem. Rev. 2012, 11, 351-359. [CrossRef]

14. Wolfgang, A.; Taffner, J.; Guimarães, R.A.; Coyne, D.; Berg, G. Novel strategies for soil-borne diseases: Exploiting the microbiome and volatile-based mechanisms toward controlling Meloidogyne-based disease complexes. Front. Microbiol. 2019, 10, 1296. [CrossRef] [PubMed]

15. Desaeger, J.A.; Watson, T.T. Evaluation of new chemical and biological nematicides for managing Meloidogyne javanica in tomato production and associated double-crops in Florida. Pest Manag. Sci. 2019, 75, 3363-3370. [CrossRef] [PubMed]

16. Yagi, K.; Williams, J.; Wang, N.Y.; Cicerone, R.J. Agricultural soil fumigation as a source of atmospheric methyl bromide. Proc Natl. Acad. Sci. USA 1993, 90, 8420-8423. [CrossRef] [PubMed]

17. Whorton, M.D.; Foliart, D.E. Mutagenicity, carcinogenicity and reproductive effects of dibromochloropropane (DBCP). Mutat. Res. 1983, 123, 13-30. [CrossRef]

18. Zhang, X.K.; Guan, P.T.; Wang, Y.L.; Li, Q.; Zhang, S.X.; Zhang, Z.Y.; Bezemer, T.M.; Liang, W.J. Community composition, diversity and metabolic footprints of soil nematodes in differently-aged temperate forests. Soil Biol. Biochem. 2015, 80, 118-126. [CrossRef]

19. Ma, Y.Y.; Li, Y.L.; Lai, H.X.; Guo, Q.; Xue, Q.H. Effects of two strains of Streptomyces on root-zone microbes and nematodes for biocontrol of root-knot nematode disease in tomato. Appl. Soil Ecol. 2017, 112, 34-41. [CrossRef]

20. Zhai, Y.L.; Shao, Z.Z.; Cai, M.M.; Zheng, L.Y.; Li, G.Y.; Yu, Z.N.; Zhang, J.B. Cyclo(1-Pro-l-Leu) of Pseudomonas putida MCCC 1A00316 isolated from Antarctic soil: Identification and characterization of activity against Meloidogyne incognita. Molecules 2019, 24, 768. [CrossRef]

21. Arthurs, S.; Dara, S.K. Microbial biopesticides for invertebrate pests and their markets in the United States. J. Invertebr. Pathol. 2019, 165, 13-21. [CrossRef]

22. Gu, Y.Q.; Mo, M.H.; Zhou, J.P.; Zou, C.S.; Zhang, K.Q. Evaluation and identification of potential organic nematicidal volatiles from soil bacteria. Soil Biol. Biochem. 2007, 39, 2567-2575. [CrossRef]

23. Bajpai, V.K.; Rahman, A.; Dung, N.T.; Huh, M.K.; Kang, S.C. In vitro inhibition of food spoilage and foodborne pathogenic bacteria by essential oil and leaf extracts of Magnolia liliflora Desr. J. Food Sci. 2008, 73, 314-320. [CrossRef]

24. Ojaghian, M.R.; Jiang, H.; Xie, G.L.; Cui, Z.Q.; Zhang, Z.; Li, B. In vitro biofumigation of brassica tissues against potato stem rot caused by Sclerotinia sclerotiorum. Plant Pathol. 2012, 28, 185-190. [CrossRef]

25. Cheng, W.L.; Yang, J.Y.; Nie, Q.Y.; Huang, D.; Yu, C.; Zheng, L.Y.; Cai, M.M.; Thomashow, L.S.; Weller, D.M.; $\mathrm{Yu}, \mathrm{Z.N}$; et al. Volatile organic compounds from Paenibacillus polymyxa KM2501-1 control Meloidogyne incognita by multiple strategies. Sci. Rep. 2017, 7, 16213. [CrossRef] [PubMed]

26. Zhai, Y.L.; Shao, Z.Z.; Cai, M.M.; Zheng, L.Y.; Li, G.Y.; Huang, D.; Cheng, W.L.; Thomasshow, L.S.; Weller, D.M.; $\mathrm{Yu}, \mathrm{Z} . \mathrm{N}$.; et al. Multiple modes of nematode control by volatiles of Pseudomonas putida 1A00316 from Antarctic soil against Meloidogyne incognita. Front. Microbiol. 2018, 9, 253. [CrossRef] [PubMed]

27. Kessler, A.; Halitschke, R.; Diezel, C.; Baldwin, I.T. Priming of plant defense responses in nature by airborne signaling between Artemisia tridentata and Nicotiana attenuata. Oecologia 2006, 148, 280-292. [CrossRef] [PubMed]

28. Wiese, J.; Imhoff, J.F. Marine bacteria and fungi as promising source for new antibiotics. Drug Dev. Res. 2019, 80, 24-27. [CrossRef]

29. Huang, D.; Shao, Z.Z.; Yu, Y.; Cai, M.M.; Zheng, L.Y.; Li, G.Y.; Yu, Z.N.; Yi, X.F.; Zhang, J.B.; Hao, F.H. Identification, characteristics and mechanism of 1-Deoxy- $N$-acetylglucosamine from deep-sea Virgibacillus dokdonensis MCCC 1A00493. Mar. Drugs 2018, 16, 52. [CrossRef]

30. Barros, A.F.; Campos, V.P.; Silva, J.C.P.; Pedroso, M.P.; Medeiros, F.H.V.; Pozza, E.A.; Reale, A.L. Nematicidal activity of volatile organic compounds emitted by Brassica juncea, Azadirachta indica, Canavalia ensiformis, Mucuna pruriens, and Cajanus cajan, against Meloidogyne incognita. Appl. Soil Ecol. 2014, 80, 34-43. [CrossRef] 
31. Aissani, N.; Urgeghe, P.P.; Oplos, C.; Saba, M.; Tocco, G.; Petretto, G.L.; Eloh, K.; Menkissogu-Spiroudi, U.; Ntalli, N.; Caboni, P. Nematicidal activity of the volatilome of Eruca sativa on Meloidogyne incognita. J. Agric. Food Chem. 2015, 63, 6120-6125. [CrossRef]

32. Popova, A.A.; Koksharova, O.A.; Lipasova, V.A.; Zaitseva, J.V.; Katkova-Zhukotskaya, O.A.; Eremina, S.I.; Mironov, A.S.; Chernin, L.S.; Khmel, I.A. Inhibitory and toxic effects of volatiles emitted by strains of Pseudomonas and Serratia on growth and survival of selected microorganisms, Caenorhabditis elegans, and Drosophila melanogaster. Biomed Res. Int. 2014, 125704.

33. Xu, Y.Y.; Lu, H.; Wang, X.; Zhang, K.Q.; Li, G.H. Effect of volatile organic compounds from bacteria on nematodes. Chem. Biodivers. 2015, 12, 1415-1421. [CrossRef]

34. Yu, J.; Du, G.; Li, R.; Li, L.; Li, Z.; Zhou, C.J.; Chen, C.C.; Guo, D.S. Nematicidal activities of bacterial volatiles and components from two marine bacteria, Pseudoalteromonas marinastrain $\mathrm{H}-42$ and Vibrio atlanticus strain S-16, against the pine wood nematode, Bursaphelenchus xylophilus. Nematology 2015, 17, 1011-1025. [CrossRef]

35. Parsons, P.A.; Spence, G.E. Acetaldehyde: A low-concentration resource and larval attractant in 3 Drosophila, species. Experientia 1981, 37, 576-577. [CrossRef]

36. Aharoni, Y.; Stewart, J.K.; Guadagni, D.G.; Mon, T.R. Thrips mortality and strawberry quality after vacuum fumigation with acetaldehyde or ethyl formate. J. AM. Soc. Hortic. Sci. 1980, 105, 926-929.

37. Stewart, J.K.; Aharoni, Y.; Hartsell, P.L.; Young, D.K. Acetaldehyde fumigation at reduced pressures to control the green peach aphid on wrapped and packed head lettuce. J. Econ. Entomol. 1980, 73, 149-152. [CrossRef]

38. Curto, G.; Dongiovanni, C.; Sasanelli, N.; Santori, A.; Myrta, A. Efficacy of dimethyl disulfide (DMDS) in the control of the root-knot nematode Meloidogyne incognita and the cyst nematode Heterodera carotae on carrot in field condition in Italy. Acta Hortic. 2014, 1044, 405-410. [CrossRef]

39. Fritsch, J.; Fouillet, T.; Charles, P.; Fargier-Puech, P.; Ramponi- Bur, C.; Descamps, S. French experiences with dimethyl disulfide (DMDS) as a nematicide in vegetable crops. Acta Hortic. 2014, 1044, 427-434. [CrossRef]

40. Faruk, M.I.; Rahman, M.L.; Mustafa, M.M.H.; Coosemans, I.J. Dimethyl disulfide-a potential biopesticide against root-knot nematode of tomato (Lycopersicon esculentum L.). Bangladesh J. Agr. Res. 2012, 36. [CrossRef]

41. Huang, Y.; Xu, C.K.; Ma, L.; Zhang, K.Q.; Duan, C.Q.; Mo, M.H. Characterisation of volatiles produced from Bacillus megaterium, YFM3.25 and their nematicidal activity against Meloidogyne incognita. Eur. J. Plant Pathol. 2010, 126, 417-422. [CrossRef]

42. Mao, L.; Jiang, H.; Zhang, L.; Zhang, Y.; Sial, M.U.; Yu, H.; Cao, A. Assessment of the potential of a reduced dose of dimethyl disulfide plus metham sodium on soilborne pests and cucumber growth. Sci. Rep. 2019, 9, 19806. [CrossRef]

43. Fialho, M.B.; Bessi, R.; Inomoto, M.M.; Pascholati, S.F. Nematicidal effect of volatile organic compounds (VOCs) on the plant-parasitic nematode Meloidogyne javanica. Summa phytopathol. 2012, 38, 152-154. [CrossRef]

44. Liarzi, O.; Bucki, P.; Miyara, S.B.; Ezra, D. Bioactive Volatiles from an endophytic Daldinia cf. concentrica isolate affect the viability of the plant parasitic nematode Meloidogyne javanica. PLoS ONE 2016, 11, e0168437.

45. Jager, L.S.; Perfetti, G.A.; Diachenko, G.W. Comparison of headspace-SPME-GC-MS and LC-MS for the detection and quantification of coumarin, vanillin, and ethyl vanillin in vanilla extract products. Food Chem. 2008, 107, 1701-1709. [CrossRef]

46. Diaz, A.; Vazquez, L.; Ventura, F.; Galceran, M.T. Estimation of measurement uncertainty for the determination of nonylphenol in water using solid-phase extraction and solid-phase microextraction procedures. Anal. Chim. Acta 2004, 506, 71-80. [CrossRef]

47. Ntalli, N.G.; Ferrari, F.; Giannakou, I.; Menkissoglu-Spiroudi, U. Synergistic and antagonistic interactions of terpenes against Meloidogyne incognita and the nematicidal activity of essential oils from seven plants indigenous to Greece. Pest Manag. Sci. 2011, 67, 341-351. [CrossRef] [PubMed]

48. Ntalli, N.G.; Manconi, F.; Leonti, M.; Maxia, A.; Caboni, P. Aliphatic ketones from Ruta chalepensis (Rutaceae) induce paralysis on root knot nematodes. J. Agric. Food Chem. 2011, 59, 7098-7103. [CrossRef] [PubMed]

49. Tajima, T.; Watanabe, N.; Kogawa, Y.; Takiguchi, N.; Kato, J.; Ikeda, T.; Kuroda, A.; Ohtake, H. Chemotaxis of the nematode Caenorhabditis elegans toward cycloheximide and quinine hydrochloride. J. Biosci. Bioeng. 2001, 91, 322-324. [CrossRef] 
50. Parida, L.; Neogi, S.; Padmanabhan, V. Effect of temperature pre-exposure on the locomotion and chemotaxis of C. elegans. PLoS ONE 2014, 9, e111342. [CrossRef]

51. Zhang, W.M.; Zhi, D.J.; Ren, H.; Wang, D.; Wang, X.; Zhang, Z.X.; Fei, D.Q.; Zhu, H.M.; Li, H.Y. Shengmai formula ameliorates pathological characteristics in AD C. elegans. Cell. Mol. Neurobiol. 2016, 36, 1291-1302. [CrossRef]

Sample Availability: Samples of the compounds are not available from the authors.

(C) 2020 by the authors. Licensee MDPI, Basel, Switzerland. This article is an open access article distributed under the terms and conditions of the Creative Commons Attribution (CC BY) license (http://creativecommons.org/licenses/by/4.0/). 